\title{
A co-authorship network-based method for understanding the evolution of a research area: A case of information systems research
}

\author{
Fangfang $\mathrm{Wei}^{1}$, Guijie Zhang ${ }^{2}$, Yuqiang Feng ${ }^{3}$, Luning Liư ${ }^{3}$, Zhen Shao ${ }^{3}$ \\ ${ }^{1}$ Business School, University of Jinan, \\ Jinan 250002, CHINA \\ ${ }^{2} S$ chool of Management Science and Engineering, \\ Shandong University of Finance and Economics, Jinan, 250014, CHINA \\ ${ }^{3}$ School of Management, Harbin Institute of Technology, \\ Harbin, 150001, CHINA \\ e-mail: sm_weiff@ujn.edu.cn; 12B910008@hit.edu.cn (corresponding author); \\ fengyq@hit.edu.cn; liuluning@hit.edu.cn; shaozhen@hit.edu.cn corresponding author)
}

\begin{abstract}
A baseline assessment research output is beneficial for policy decision makers to promote research. This paper presents a co-authorship network-based method to quantify and describe the scholarly publishing of a certain research field. To make our analysis more precise, we firstly generalized the measures used in previous literatures into formulas and analyzed the significance of the measures. We then classified our study into overall, individual, institutional and international levels to make our analysis clearer and more reasonable. Finally, we conduct a research of the structure, characteristics and development trend of coauthorship network based on publication output in top three journals in the field of information systems from 1993 to 2012. By synthetical analysis, our research results are helpful to know the productivity patterns, trends of the published research and status of international collaboration in this field.
\end{abstract}

Keywords: Social network; Co-authorship network; Publication output; Information systems research

\section{INTRODUCTION}

To evaluate publication productivity of scientific researches, scholars in the field of library and information science tend to build co-authorship network of the corresponding fields (Abbasi et al. 2011; Larivière, Gingras and Archambault 2006; Zhai et al. 2014). In a coauthorship network, scientists are connected when they publish papers together, where nodes represent scientists while edges represent co-authorship relations (Newman 2001a). 
In recent years, there has been a sharp increase in the number of articles addressing the topic of collaborations of publication among scholars (Chen, Börner and Fang 2013; Larivière, Gingras and Archambault 2006). Researches on co-authorship network have essential functions that combine distributed knowledge and method together to create novel knowledge (Heinze and Kuhlmann, 2008). Through collaboration behaviors, researchers have the opportunities to share their knowledge which are crucial for knowledge creation and research output (Abbasi et al. 2011).

In recent years, a large number of scholars have conducted empirical studies to investigate the productivity patterns, trends of the publication, etc. (Ronda-Pupo and Guerras-Martín 2010; Zhai et al. 2014). Though previous studies have proceeded with plenty of empirical analysis of the characteristics of collaboration networks in a wide range of disciplines (RondaPupo and Guerras-Martín 2010; Yazit and Zainab 2007; Zhai et al. 2014) by synthetical analysis, we find out that most of them have not provided the formulas used in their paper, which may confuse readers. This paper focused on this issue and generalized the measures used in previous literatures into formulas and analyzed the significance of the measures to make our analysis more precise. This is the first objective of this paper.

To make our analysis clearer and more reasonable, we classified our study from overall, individual, institutional and international perspectives. From the overall perspective, we can obtain the overall structural characteristics of a certain field as a whole (Liu et al. 2005). From the individual perspective, we can discover the different opportunities and constraints that shape individuals' publishing behaviors (Yin et al. 2006). From the institutional perspective, we can capture the distribution of high-publication institutions from the location of them (Liu, Chang and Chen 2012). From the international perspective, we can explore the rules of collaboration publication between countries all over the world (Zhai et al. 2014). This is the second objective of this paper.

Although a wide range of disciplines have been studied (Tang and Shapira 2011; Uddin et al., 2012), little attention has been paid to the scholarly publishing in the field of information systems. We carried out a detailed analysis of the IS field in the last twenty years so as to know the productivity patterns, trends of the published research and status of international collaboration in this field. This is the third objective of this paper.

This study has a significant practical contribution for international scholars since this paper not only provides a more profound understanding about the publication productivity and evolutionary trend of collaboration network in the field of information systems but also offers a comprehensive analysis method applied to other fields to analyze the state of scholarly publication.

\section{ANALYTICAL METHOD}

To provide an applicable method to analyze publication productivity, drawing upon the abundant previous literatures (Uddin et al. 2012; Zhai et al. 2014), we abstracted and generalized the measures used in their papers into formulas and analyzed the significance of the measures which make our analysis more precise. The details of analysis are shown in Table 1 to 4 . 
Table 1: Details of Analysis from the Overall Perspective

\begin{tabular}{|c|c|c|}
\hline Measures & Formula & Significance \\
\hline $\begin{array}{l}\text { Statistical analysis } \\
\text { of collaboration of } \\
\text { articles published } \\
\text { in the top three } \\
\text { journals }\end{array}$ & $\begin{array}{c}P_{i j}=\frac{a_{i j}}{A_{i}} ; P_{j}=\frac{\sum_{i=1}^{3} a_{i j}}{\sum_{i=1}^{3} A_{i}} \\
a_{i j}: \text { the number of papers which have } \mathrm{j} \text { authors } \\
\text { published in journal } \mathrm{i} ; \\
A_{i}: \text { the number of papers published in journal } \mathrm{i} ; \\
P_{i j}: \text { the percentage of papers which have } \mathrm{j} \\
\text { authors published in journal } \mathrm{i} ; \\
P_{j} ; \text { the percentage of papers which have } \mathrm{j} \text { authors } \\
\text { published in top three journals }\end{array}$ & $\begin{array}{l}\text { From this measure we can learn the } \\
\text { distribution of the number of } \\
\text { authors in single article (Zhai et al. } \\
\text { 2014) and the tendency of } \\
\text { collaboration among researchers in } \\
\text { producing scientific publications } \\
\text { (Uddin et al. 2012) }\end{array}$ \\
\hline $\begin{array}{l}\text { Evolution of } \\
\text { collaboration } \\
\text { degree of articles } \\
\text { published in the } \\
\text { top three journals }\end{array}$ & $\begin{array}{c}D_{i k}=\frac{\sum_{j=1}^{n} j * a_{i j k}}{A_{i k}} ; D_{k}=\frac{\sum_{i=1}^{3} \sum_{j=1}^{n} j * a_{i j k}}{\sum_{i=1}^{3} A_{i k}} \\
a_{i j k}: \text { the number of papers which have } \mathrm{j} \text { authors } \\
\text { of journal } \mathrm{i} \text { in the year of } \mathrm{k} ; \\
D_{i k}: \text { the collaboration degree of journal } \mathrm{i} \text { in the } \\
\text { year of } \mathrm{k} ; \\
D_{k}: \text { the collaboration degree of the top three } \\
\text { journals in the year of } \mathrm{k} ;\end{array}$ & $\begin{array}{l}\text { This measure refers to the average } \\
\text { number of co-authors of these } \\
\text { articles in a certain period (Zhai et al. } \\
2014 \text { ) and the tendency of scientific } \\
\text { collaboration of publication with the } \\
\text { passage of time. }\end{array}$ \\
\hline $\begin{array}{l}\text { Evolution of the } \\
\text { average distance } \\
\text { in the whole co- } \\
\text { authorship } \\
\text { network }\end{array}$ & $\begin{array}{l}\mathrm{L}=\frac{1}{N^{2}} \sum_{j=1}^{N} \sum_{i}^{N} d_{i j} \\
\mathrm{~N} \text { : the number of nodes in the whole network; } \\
d_{i j} \text { : the distance between the node } v_{i} \text { and } v_{j} ;\end{array}$ & $\begin{array}{l}\text { This measure implies that one } \\
\text { scholar in the network needs how } \\
\text { many steps to reach another one in } \\
\text { average which means scientific } \\
\text { information can be obtained easily } \\
\text { or not by peoples who demand them } \\
\text { (Newman 2001b) }\end{array}$ \\
\hline $\begin{array}{l}\text { Evolution of } \\
\text { network density of } \\
\text { whole co- } \\
\text { authorship } \\
\text { network }\end{array}$ & $\begin{array}{l}\text { Density }=\frac{2 \mathrm{M}}{\mathrm{N}(\mathrm{N}-1)} \\
\mathrm{M}: \text { the number of ties in the whole network; } \\
\mathrm{N} \text { : the number of nodes in the whole network; }\end{array}$ & $\begin{array}{l}\text { This measure shows the ratio of the } \\
\text { actual and the maximum possible } \\
\text { number of edges which describes } \\
\text { network's general level of scholarly } \\
\text { collaboration relationship close or } \\
\text { not (Abbasi et al. 2011). }\end{array}$ \\
\hline
\end{tabular}

Table 2: Details of Analysis from the Individual Perspective

\begin{tabular}{|c|c|c|}
\hline Measures & Formula & Significance \\
\hline $\begin{array}{l}\text { Distribution of number of } \\
\text { scholars publishing } \\
\text { articles in the top three } \\
\text { journals }\end{array}$ & $\begin{array}{l}T_{i}=\sum_{j=1}^{2298} t_{j} \\
T_{i} \text { : the number of scholars publishing } \\
\text { the number of } \mathrm{i} \text { articles in the top three } \\
\text { journals } \\
t_{j} \text { : if author } \mathrm{j} \text { published the number of } \mathrm{i} \\
\text { articles, } t_{j}=1 ; \text { otherwise } t_{j}=0\end{array}$ & $\begin{array}{l}\text { The distribution of the number of } \\
\text { scholars publishing articles in the top } \\
\text { journals displays some phenomenon, } \\
\text { such as long tail, exponent form, etc., } \\
\text { and we can analyze and find out the } \\
\text { reason behind this (Zhai et al. 2014) }\end{array}$ \\
\hline $\begin{array}{l}\text { Ten top authors ranked by } \\
\text { the number of articles } \\
\text { published in the top three } \\
\text { journals }\end{array}$ & $\begin{array}{l}U_{i}=\max u_{j} \\
U_{i}: \text { the ten top authors ranked by the } \\
\text { number of articles published in the top } \\
\text { three journals } \\
u_{j}: \text { the number of articles published in } \\
\text { the top three journals by author } \mathrm{j}\end{array}$ & $\begin{array}{l}\text { This measure reveals which authors } \\
\text { occupy key roles in the co-authorship } \\
\text { network (Chen, Börner and Fang 2013) } \\
\text { and the change of the elite scholars in } \\
\text { the field of the information systems } \\
\text { with the passage of time. }\end{array}$ \\
\hline $\begin{array}{l}\text { Evolution of the yearly } \\
\text { increased and the } \\
\text { accumulated number of } \\
\text { scholars in the whole co- } \\
\text { authorship network }\end{array}$ & $\begin{array}{l}A_{i}=\sum_{j=1}^{i} a_{j} \\
A_{i}: \text { total number of scholars from the } \\
\text { first year to the year of } \mathrm{i} \\
a_{j} \text { : the number of scholars in the year of } \\
\mathrm{j}\end{array}$ & $\begin{array}{l}\text { This measure reflects the growth of } \\
\text { the number of scholars whose papers } \\
\text { were absorbed in the top journals as } \\
\text { the time goes on (Chen, Börner and } \\
\text { Fang 2013) and the corresponding } \\
\text { changing rules. }\end{array}$ \\
\hline
\end{tabular}


Table 3: Details of Analysis from the Institutional Perspective

\begin{tabular}{|c|c|c|}
\hline Measures & Formula & Significance \\
\hline $\begin{array}{l}\text { Distribution of } \\
\text { number of } \\
\text { institutions } \\
\text { publishing articles in } \\
\text { the top three } \\
\text { journals }\end{array}$ & $\begin{array}{l}\qquad M_{i}=\sum_{j=1}^{733} m_{j} \\
M_{i} \text { : the number of institutions publishing } \\
\text { the number of } \mathrm{i} \text { articles in the top three } \\
\text { journals } \\
m_{j}: \text { if institution } \mathrm{j} \text { published the number of } \\
\mathrm{i} \text { articles, } m_{j}=1 ; \text { otherwise } m_{j}=0\end{array}$ & $\begin{array}{l}\text { To some extent, this measure reflects } \\
\text { the reputation of research } \\
\text { institutions which can attract high } \\
\text { qualified students from all over the } \\
\text { world, introduce outstanding } \\
\text { scholars, and obtain government } \\
\text { funding and social donation (Abbasi } \\
\text { et al. 2011) }\end{array}$ \\
\hline $\begin{array}{l}\text { Evolution of the } \\
\text { yearly increased and } \\
\text { the accumulated } \\
\text { number of } \\
\text { institutions in the } \\
\text { whole co-authorship } \\
\text { network }\end{array}$ & $\begin{array}{l}B_{i}=\sum_{j=1}^{i} b_{j} \\
B_{i}: \text { total number of institutions from the } \\
\text { first year to the year of } \mathrm{i} \\
b_{j}: \text { the number of institutions in the year } \\
\text { of } \mathrm{j}\end{array}$ & $\begin{array}{l}\text { This measure reflects the growth of } \\
\text { the number of institutions whose } \\
\text { papers were absorbed in the top } \\
\text { journals as the time goes on (Chen, } \\
\text { Börner and Fang 2013) and indicates } \\
\text { how many institutions is achieving } \\
\text { and has achieved international } \\
\text { advanced level and their distribution } \\
\text { in the world. }\end{array}$ \\
\hline $\begin{array}{l}\text { Top ten institutions } \\
\text { ranked by the } \\
\text { number of articles } \\
\text { published in the top } \\
\text { three journals }\end{array}$ & $\begin{array}{c}V_{i}=\max v_{j} \\
V_{i}: \text { the ten top institutions ranked by the } \\
\text { number of articles } \\
v_{j}: \text { the number of articles published in the } \\
\text { top three journals by institution } \mathrm{j}\end{array}$ & $\begin{array}{l}\text { This measure can give us a help when } \\
\text { analyzing which institutions occupy } \\
\text { key roles in the institutions } \\
\text { collaboration network, (Chen, Börner } \\
\text { and Fang 2013) the evolution law and } \\
\text { the reason behind this. }\end{array}$ \\
\hline
\end{tabular}

Table 4: Details of Analysis from the International Perspective

\begin{tabular}{|c|c|c|}
\hline Measures & Formula & Significance \\
\hline $\begin{array}{l}\text { Distribution of } \\
\text { number of countries } \\
\text { publishing articles in } \\
\text { the top three } \\
\text { journals }\end{array}$ & $\begin{array}{l}\qquad N_{i}=\sum_{j=1}^{40} n_{j} \\
M_{i} \text { : the number of countries publishing the } \\
\text { number of } \mathrm{i} \text { articles in the top three } \\
\text { journals } \\
n_{j}: \text { if country } \mathrm{j} \text { published the number of } \mathrm{i} \\
\text { articles, } t_{j}=1 ; \text { otherwise } t_{j}=0\end{array}$ & $\begin{array}{l}\text { This measure is useful when analyzing } \\
\text { the evolution law of countries } \\
\text { publishing articles in the top journals } \\
\text { and the results can give the visiting } \\
\text { scholars a hand when making a } \\
\text { decision which country to visit. }\end{array}$ \\
\hline $\begin{array}{l}\text { Evolution of the } \\
\text { yearly increased and } \\
\text { the accumulated } \\
\text { number of countries } \\
\text { in the whole co- } \\
\text { authorship network }\end{array}$ & $\begin{array}{l}\qquad C_{i}=\sum_{j=1}^{i} c_{j} \\
C_{i} \text { : total number of countries from the first } \\
\text { year to the year of } \mathrm{i} \\
c_{j} \text { : the number of countries in the year of } \mathrm{j}\end{array}$ & $\begin{array}{l}\text { This measure reflects the growth of } \\
\text { the number of countries whose } \\
\text { papers were absorbed in the top } \\
\text { journals as the time goes on (Chen, } \\
\text { Börner and Fang 2013) and reveals } \\
\text { how many countries is achieving and } \\
\text { has achieved international advanced } \\
\text { level. }\end{array}$ \\
\hline $\begin{array}{l}\text { Top ten countries or } \\
\text { territories ranked by } \\
\text { the number of } \\
\text { articles published in } \\
\text { the top three } \\
\text { journals }\end{array}$ & $\begin{array}{c}W_{i}=\max w_{j} \\
W_{i}: \text { the ten top countries ranked by the } \\
\text { number of articles published in the top } \\
\text { three journals } \\
w_{j}: \text { the number of articles published in the } \\
\text { top three journals by country } \mathrm{j}\end{array}$ & $\begin{array}{l}\text { From this measure, we can learn } \\
\text { which countries or territories occupy } \\
\text { key roles in the countries } \\
\text { collaboration network, (Chen, Börner } \\
\text { and Fang 2013) the evolution law and } \\
\text { the scope of collaboration in the } \\
\text { world. }\end{array}$ \\
\hline
\end{tabular}




\section{DATA COLLECTION AND UNIFICATION}

According to Peffers and Ya (2003), Rainer and Miller (2005), and Dennis et al. (2006), Management Information Systems Quarterly (MISQ), Information Systems Research (ISR) and Journal of Management Information Systems (JMIS) are recognized as the three elite journals in the field of information systems. We chose the top three academic journals as the data sources to extract the information of articles and construct the co-authorship networks to analyze the status and evolutionary trend of collaboration network in the field of information systems.

The data was retrieved from the EBSCO's Business Source Premier during December 2012 and articles were downloaded from the top three journals from January 1, 1993 to December 31, 2012. Then we extracted the bibliographic information such as article titles, authors, author institutions and countries for further analysis. After cleaning the publication data, there are totally 1745 articles contributed by 2298 unique authors, 733 unique institutions and 40 unique countries or regions. During the procedure of data collection, papers written by editors and papers with only one author were excluded from our dataset, since an article is considered as the result of a collaborative activity when it is written by more than one author (Larivière, Gingras and Archambault 2006).

\section{RESULTS}

\section{Overall Analysis of Co-authorship Network}

The distribution of the number of authors in a single article published in the top three journals in the last two decades is shown in Table 5. We can see that most articles (72.6\% $75.3 \%)$ are completed by two or three authors while only a small number of articles $(2.7 \%$ $4.0 \%)$ are written by more than five authors. These results indicate that papers written by two or three authors are the most effective cooperation pattern.

Table 5: Statistical Analysis of Collaborative Papers Published in the Top Three Journals

\begin{tabular}{|c|c|c|c|c|c|c|}
\hline \multicolumn{2}{|c|}{ Number of authors } & \multicolumn{5}{|c|}{ Distribution of number of authors a in single article } \\
\hline & & 1 & 2 & 3 & 4 & $>=5$ \\
\hline \multirow{4}{*}{$\begin{array}{l}\text { Number of articles } \\
\text { (percent) }\end{array}$} & Total & $254(12.7 \%)$ & $791(39.6 \%)$ & $684(34.2 \%)$ & $205(10.3 \%)$ & $65(3.3 \%)$ \\
\hline & MISQ & $98(15.4 \%)$ & $282(44.2 \%)$ & $181(28.4 \%)$ & $59(9.2 \%)$ & $18(2.8 \%)$ \\
\hline & ISR & $57(10.1 \%)$ & $227(40.2 \%)$ & $198(35.1 \%)$ & $67(11.9 \%)$ & $15(2.7 \%)$ \\
\hline & JMIS & 99(12.4\%) & $282(35.4 \%)$ & $305(38.3 \%)$ & $79(9.9 \%)$ & $32(4.0 \%)$ \\
\hline
\end{tabular}

The average collaboration degree of articles refers to the average number of co-authors of these published articles in a certain period (Zhai et al. 2014). To understand the historical changing rules of collaboration degree, we drew the evolution chart of collaboration degree of articles published in the top three journals from 1993 to 2012. From Figure 1 we can see that collaboration degree of articles published in the three elite journals fluctuated from 1.89 to 3.04. The whole curve rises as a whole which means collaboration behaviors are popular among scholars in the field of IS. Through collaboration behaviors, researchers could share their knowledge (Abbasi et al. 2011). Combining distributed knowledge and method together, collaboration among scholars has an irreplaceable role in the process of knowledge creation and publication output (Heinze and Kuhlmann 2008). 
To learn the evolution of average distance in the whole co-authorship network of the top three journals, we present Figure 2. The average distance is affected by two kinds of newly added links: the external links and internal links (Elmacioglu and Lee 2009). By establishing new paths between new vertices and the existing ones, the external links have a significant impact on increasing the average distance, while by cresting new paths between the existing vertices, the internal links play a key role in decreasing the average distance. Affected by the two fundamentally different types of newly added links, the average distance presents a series of changes. As is shown in Figure 2, by the year of 2012, the average distance achieves 5.85 with 2298 authors. This implies that one scholar in the network only needs five or six steps to reach another one, which means scientific information can be obtained easily by researchers who demand them (Newman 2001a).

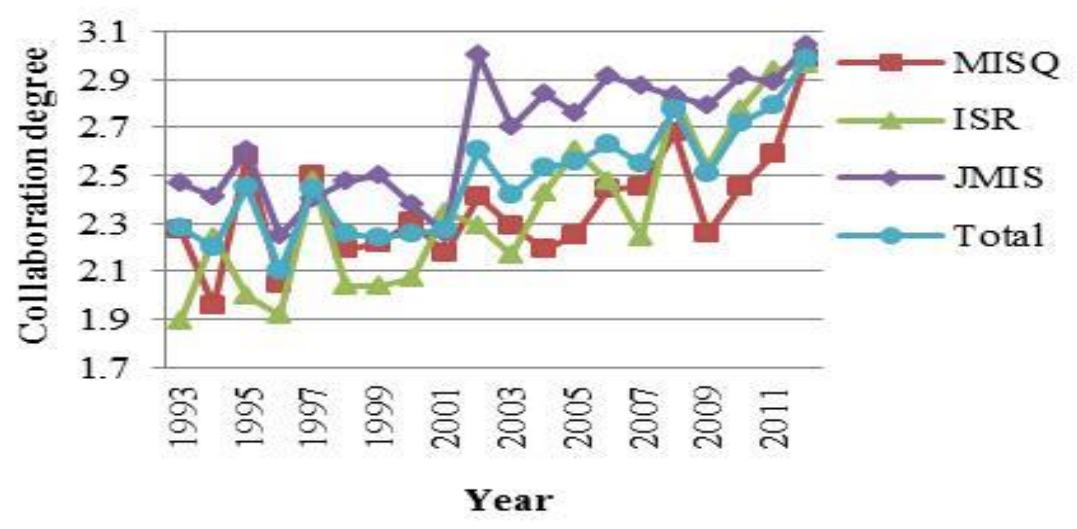

Figure 1: Evolution of Collaboration Degree of Articles Published in the Top Three Journals

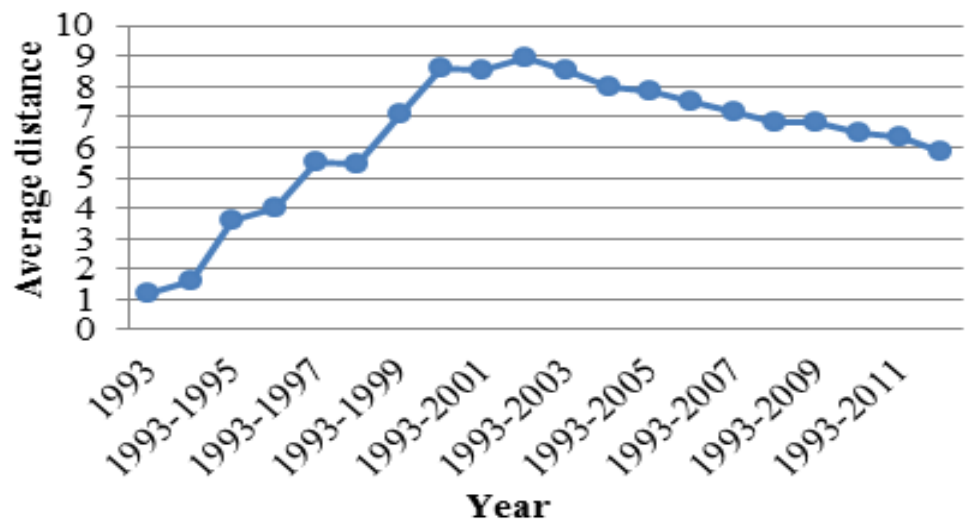

Figure 2: Evolution of the Average Distance in the Whole Co-authorship Network

The density of a graph is defined as the ratio of the actual number of edges and the maximum possible number of edges. Table 6 illustrates the evolution of the network density of the whole co-authorship network. As Table 6 shows, the whole co-authorship network density in information systems faces a tendency of decline, from 0.0043 to 0.0016 . After analysis, we found that the primary cause is the number of scholars joining the collaboration network has been increased, from 576 to 2298 , which leads the maximum possible number of edges goes up rapidly. Nevertheless, since the growth rate of the number of collaboration among scholars in the network is relatively limited, the network density goes down. Since network Page | 6 
density describes the general level of connection among vertices in the network (Liu, Shan and $\mathrm{Yu}$ 2011), this result means that in the field of information systems, the scholarly publication relationship among authors is not so close. This phenomenon may be related to the diversification of the research topics in the field of information systems and scholars with the same research topic tend to produce more research cooperation.

Table 6: Evolution of Network Density of Whole Co-authorship Network

\begin{tabular}{c||c||c||c||c}
\hline \hline Years & $1993-1997$ & $1993-2002$ & $1993-2007$ & $1993-2012$ \\
\hline \hline Network density & 0.0043 & 0.0028 & 0.0020 & 0.0016 \\
\hline \hline
\end{tabular}

\section{Analysis at the Individual Level}

As is well known, in the field of scientometrics, one of the key indexes to evaluate a scholar's contribution is his or her number of published articles (Zhai et al. 2014). Figure 3 indicates that about 65 percent of scholars published only one article while only 2 of percent scholars published more than ten articles in the three elite journals. Most scholars (about 94\%) published no more than five articles. The distribution of the number of articles published in the three elite journals displays "long tail" phenomenon. One of the reasons is that the publication frequency of the premier journals is too long and top journals in the field of information systems need to publish bimonthly (Valacich et al. 2006). In this situation, the competition of publishing an article in elite journals is very fierce.

In order to observe the changing rules of the number of scholars who published articles in the top three journals in the last two decades, we calculated the related numerical values and illustrated them in Figure 4. As displayed in Figure 4, the yearly increased scholars fluctuate but keep stable, which are approximately 100 . The accumulated number of scholars increases year after year. By the year of 2012, the number of total authors reaches to 2298 . This means that the field of information systems has a stable development in the number of total scholars.

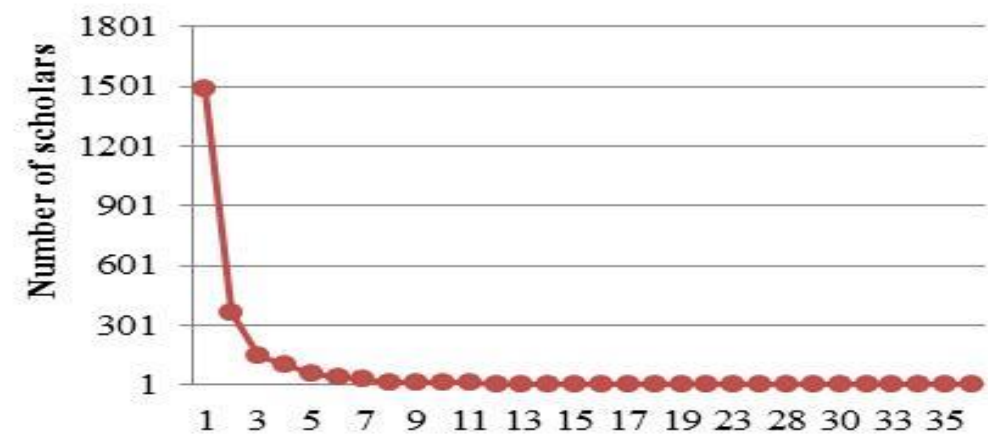

Number of articles

Figure 3: Distribution of Number of Scholars Publishing Articles in the Top Three Journals 


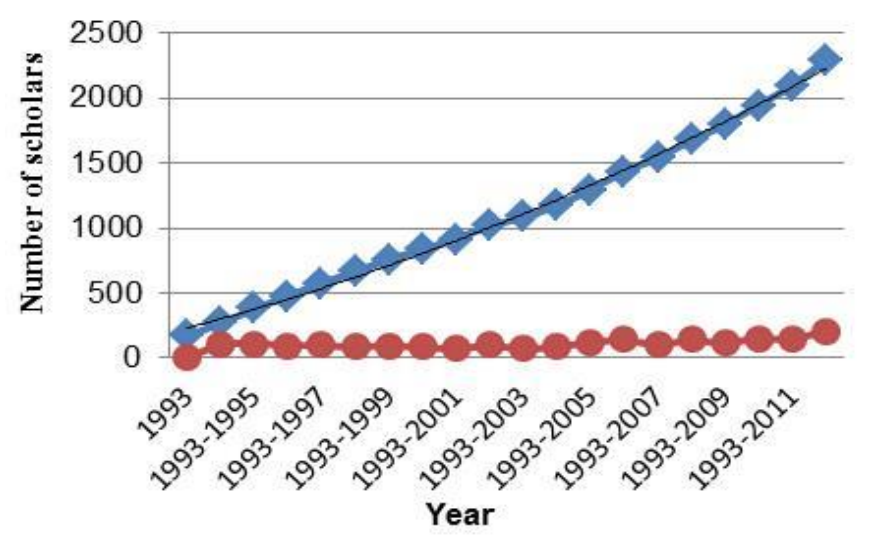

Figure 4: Evolution of the Yearly Increased and the Accumulated Number of Scholars

Table 7 shows the top ten authors ranked by the published number of articles, degree centrality and betweenness centrality in the three elite journals in the last two decades. The lists of authors ranked by the published number of articles, betweenness centrality and degree centrality are quite different from each other. The reasons behind the differences are described as follows. Authors' published number of articles identifies the amount of the outcome of researchers. Degree centrality features the number of attachments of vertices in the network. Whereas betweenness centrality measures the importance of a vertex corresponding to the number of paths in which the vertex participates in the network. The selection of the indicators depends on the purpose of the researchers' study.

Table 7: Top Ten Authors Publishing in the Top Three Journals between 1993 and 2012

\begin{tabular}{|c|c|c|c|c|c|}
\hline \multicolumn{2}{|c|}{ Number of published articles } & \multicolumn{2}{|l|}{ Degree centrality } & \multicolumn{2}{|c|}{ Betweenness centrality } \\
\hline Izak Benbasat & 49 & Izak Benbasat & 55 & Izak Benbasat & 261152 \\
\hline Robert J. Kauffman & 35 & Alan R. Dennis & 50 & Alan R. Dennis & 243793 \\
\hline Andrew B. Whinston & 33 & Jay F. Nunamaker & 49 & Alok Gupta & 179185 \\
\hline Varun Grover & 33 & Detmar W. Straub & 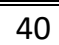 & Jay F. Nunamaker & 163599 \\
\hline Jay F. Nunamaker & 32 & Varun Grover & 39 & Detmar W. Straub & 143044 \\
\hline Alan R. Dennis & 30 & Andrew B. Whinston & 39 & Ritu Agarwal & 114728 \\
\hline Ritu Agarwal & 29 & Robert J. Kauffman & 38 & Robert J. Kauffman & 108495 \\
\hline Detmar W. Straub & 28 & Ritu Agarwal & 38 & Vallabh Sambamurthy & 103915 \\
\hline Eric K. Clemons & 26 & Alok Gupta & 34 & Rajiv D. Banker & 94471 \\
\hline Robert O. Briggs & 23 & Vallabh Sambamurthy & 29 & Andrew B. Whinston & 90371 \\
\hline
\end{tabular}

\section{Analysis at the Institutional level}

Performance evaluation is an inevitable function of management at institutional level. All the research institutions pursue good reputation since good reputation can attract high qualified students from all over the world, introduce outstanding scholars, and obtain government funding and social donation (Abbasi, Altmann and Hossain 2011). The number of high-level papers published in the elite journals is one of the key indicators that reflects the research capability of the research institutions. From Figure 5, we observe that 401 institutions (55\%) publish only one paper. Specifically, Georgia State University is the most productive institution that published 103 papers. A total of 92 institutions (12\%) published more than ten papers in the three elite journals while most institutions (80\%) published less than six articles. As is explained later, this phenomenon demonstrates that there are many excellent 
scholars in some institutions who contribute greatly to the reputation of the institutions.

Increasing the number of publications in the top three journals is extremely beneficial to enhance the reputation of the institutions in the field of information systems all over the world. For this reason, we illustrate the changing rules of the number of institutions published articles in the top three journals from 1993 to 2012 in Figure 6. As is shown in Figure 6 , by the year of 2012, the accumulated number of institutions reaches to 733 . In addition, the number of yearly increased institutions is around 30 each year, except for the last two years of 2011 and 2012, which are 51 and 58 respectively. This result indicates that more and more institutions have increased research abilities and achieved international advanced level. And the growth trend is relatively stable.

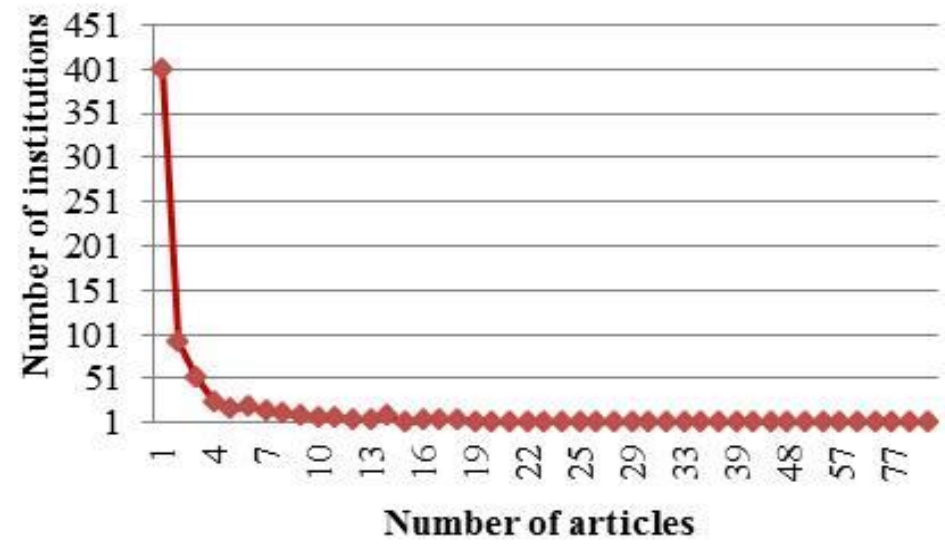

Figure 5: Distribution of Number of Institutions Publishing Articles in the Top Three Journals

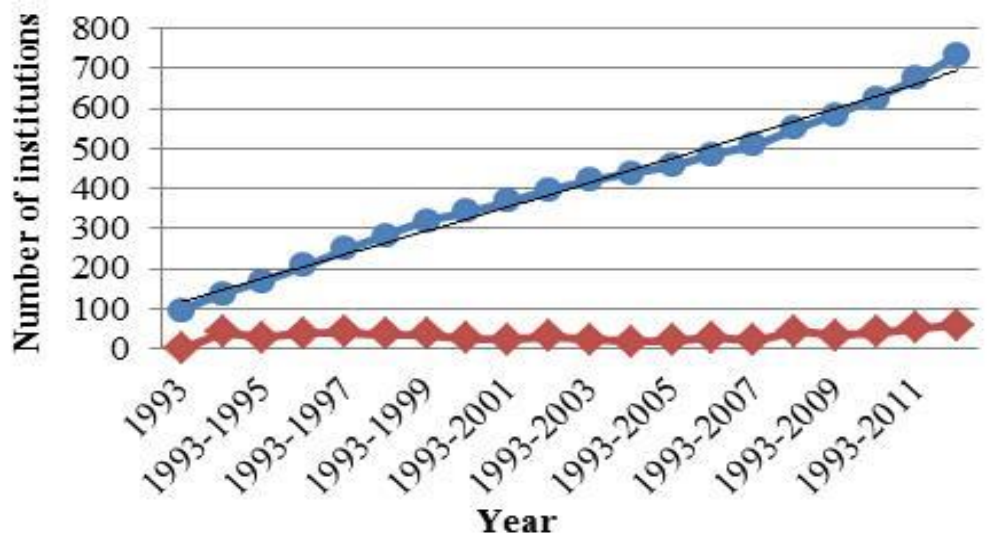

Figure 6: Evolution of the Yearly Increased and the Accumulated Number of Institutions

When analyzing the evolution law of institution collaboration networks, we found that a few famous institutions maintain their leading position in the top ten lists. Since the scholarly outcomes of institutions come from scholars, these institutions may occupy more human resources. Besides, the ranking of an entire institution can be influenced by even one or two authors (Chen, Börner and Fang 2013). For example, Professor Ritu Agarwal published 26 articles which occupy about 34 percent of University of Maryland. University of British Columbia has totally published 71 articles. Among all the 71 articles, there are 49 articles (69\%) written by Professor Izak Benbasat. 
Table 8: Institution Ranking of Number of Articles Published in the Top Three Journals

\begin{tabular}{|c|c|c|c|c|c|c|c|}
\hline \multicolumn{2}{|l|}{ 1993-1997 } & \multicolumn{2}{|l|}{$1993-2002$} & \multicolumn{2}{|c|}{$1993-2007$} & \multicolumn{2}{|c|}{$1993-2012$} \\
\hline $\begin{array}{l}\text { New York } \\
\text { University }\end{array}$ & 23 & $\begin{array}{l}\text { University of } \\
\text { Arizona }\end{array}$ & 37 & $\begin{array}{l}\text { Georgia State } \\
\text { University }\end{array}$ & 60 & $\begin{array}{l}\text { Georgia State } \\
\text { University }\end{array}$ & 103 \\
\hline $\begin{array}{l}\text { University of } \\
\text { Arizona }\end{array}$ & 20 & $\begin{array}{l}\text { University of } \\
\text { Georgia }\end{array}$ & 35 & $\begin{array}{l}\text { University of } \\
\text { Arizona }\end{array}$ & 54 & $\begin{array}{l}\text { University of } \\
\text { Arizona }\end{array}$ & 85 \\
\hline $\begin{array}{l}\text { University of } \\
\text { Georgia }\end{array}$ & 18 & $\begin{array}{l}\text { Georgia State } \\
\text { University } \\
\end{array}$ & 33 & $\begin{array}{l}\text { University of } \\
\text { Minnesota }\end{array}$ & 50 & $\begin{array}{l}\text { University of } \\
\text { Minnesota }\end{array}$ & 77 \\
\hline $\begin{array}{l}\text { University of } \\
\text { South Carolina }\end{array}$ & 16 & $\begin{array}{l}\text { New York } \\
\text { University }\end{array}$ & 29 & $\begin{array}{l}\text { University of } \\
\text { British } \\
\text { Columbia }\end{array}$ & 45 & $\begin{array}{l}\text { University of } \\
\text { Maryland }\end{array}$ & 77 \\
\hline $\begin{array}{l}\text { University of } \\
\text { Colorado }\end{array}$ & 14 & $\begin{array}{l}\text { University of } \\
\text { Minnesota }\end{array}$ & 26 & $\begin{array}{l}\text { New York } \\
\text { University }\end{array}$ & 42 & $\begin{array}{l}\text { University of } \\
\text { British } \\
\text { Columbia }\end{array}$ & 71 \\
\hline $\begin{array}{l}\text { Carnegie Mellon } \\
\text { University }\end{array}$ & 12 & $\begin{array}{l}\text { University of } \\
\text { Pennsylvania }\end{array}$ & 24 & $\begin{array}{l}\text { University of } \\
\text { Georgia }\end{array}$ & 42 & $\begin{array}{l}\text { Carnegie } \\
\text { Mellon } \\
\text { University }\end{array}$ & 66 \\
\hline $\begin{array}{l}\text { University of } \\
\text { Minnesota }\end{array}$ & 12 & $\begin{array}{l}\text { University of } \\
\text { California }\end{array}$ & 24 & $\begin{array}{l}\text { University of } \\
\text { California }\end{array}$ & 40 & $\begin{array}{l}\text { University of } \\
\text { California }\end{array}$ & 57 \\
\hline $\begin{array}{l}\text { University of } \\
\text { California }\end{array}$ & 11 & $\begin{array}{l}\text { Indiana } \\
\text { University }\end{array}$ & 24 & $\begin{array}{l}\text { Indiana } \\
\text { University }\end{array}$ & 40 & $\begin{array}{l}\text { University of } \\
\text { Georgia }\end{array}$ & 56 \\
\hline $\begin{array}{l}\text { University of } \\
\text { Pennsylvania }\end{array}$ & 11 & $\begin{array}{l}\text { University of } \\
\text { British Columbia }\end{array}$ & 23 & $\begin{array}{l}\text { University of } \\
\text { Maryland }\end{array}$ & 38 & $\begin{array}{l}\text { New York } \\
\text { University } \\
\end{array}$ & 56 \\
\hline $\begin{array}{l}\text { National } \\
\text { University of } \\
\text { Singapore }\end{array}$ & 11 & $\begin{array}{l}\text { University of } \\
\text { Colorado }\end{array}$ & 23 & $\begin{array}{l}\text { University of } \\
\text { Texas }\end{array}$ & 36 & $\begin{array}{l}\text { National } \\
\text { University of } \\
\text { Singapore }\end{array}$ & 55 \\
\hline
\end{tabular}

\section{Analysis at the National level}

In order to know the distribution of number of countries publishing articles in the top three journals in the last two decades, we illustrate the details in Figure 7. The most fertile countries or regions are USA, Canada and Hong Kong, with 1495, 198 and 104 papers respectively. These three countries and regions obtain 82 percent of the total papers, while some other countries just have one paper. This result means that quite a lot of outstanding scholars and educational resources concentrate upon USA, Canada and Hong Kong, especially USA, which holds eight institutions of the top ten. As a result, these three countries and regions may be the first choice for visiting scholars in the information systems discipline.

We draw Figure 8 to explore the changing rules of the number of countries publishing articles in the top three journals from 1993 to 2012. As is illustrated in Figure 8, the accumulated number of countries is stable in some years, such as the year of 1996 and 1997, which are both 20 countries in total. Besides, there are all 27 countries in the year of 2001, 2002 and 2003 , suggesting that the corresponding yearly increased countries are all 0 . In addition, the yearly increased countries are in a low range, from 0 to 4 . From this result we observe that, the growth of the number of countries is slow compared with authors and institutions. This phenomenon may result from the small scale of the number of countries and regions. 


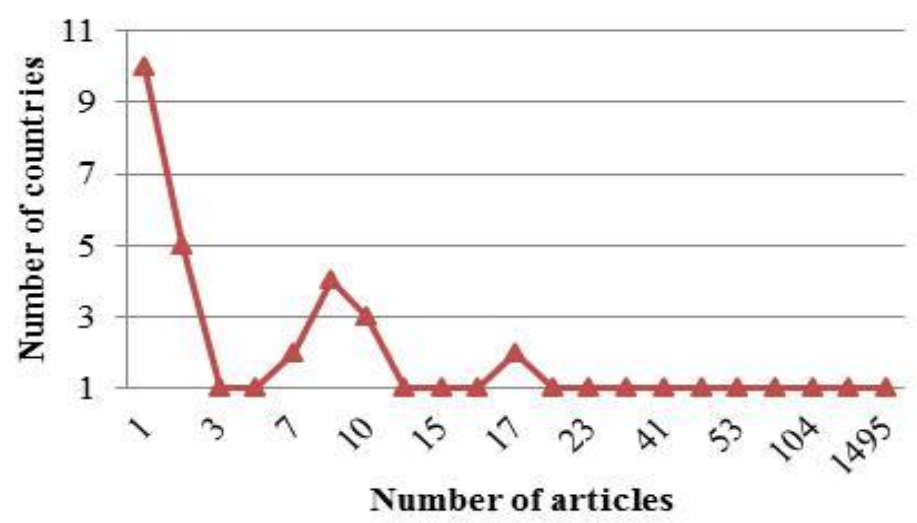

Figure 7. Distribution of Number of Countries Publishing Articles in the Top Three Journals

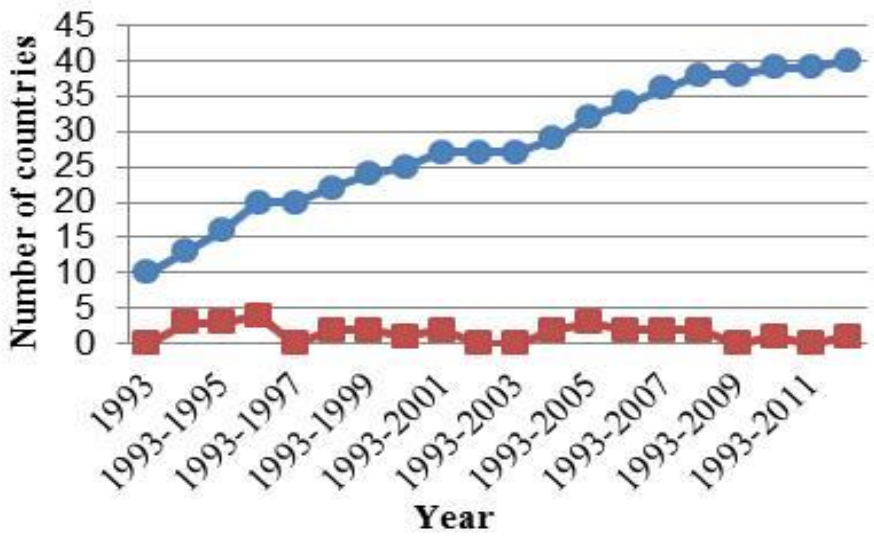

Figure 8. Evolution of the Yearly Increased and the Accumulated Number of Countries

As illustrated in Table 9, eight of the top ten countries, which are USA, Canada, Hong Kong, Singapore, Korea, UK, Australia, and Netherlands, maintain their leading position throughout the twenty years. In the four time periods, USA has 280, 571, 953 and 1495 articles, respectively, which are far beyond than that of any other countries. China (mainland) and Germany, join the list of top ten countries, and this indicates that the level of scientific research of the two countries have gained considerable development in recent years.

Table 9: Top Countries Ranked by the Number of Articles Published in the Top Three Journals

\begin{tabular}{|c|c|c|c|c|c|c|c|}
\hline \multicolumn{2}{|c|}{ 1993-1997 } & \multicolumn{2}{|c|}{ 1993-2002 } & \multicolumn{2}{|c|}{$1993-2007$} & \multicolumn{2}{|c|}{$1993-2012$} \\
\hline USA & 280 & USA & 571 & USA & 953 & USA & 1495 \\
\hline Canada & 41 & Canada & 75 & Canada & 124 & Canada & 198 \\
\hline UK & 17 & Singapore & 26 & Singapore & 46 & Hong Kong & 104 \\
\hline Singapore & 14 & UK & 24 & Hong Kong & 43 & Singapore & 86 \\
\hline Hong Kong & 8 & Hong Kong & 24 & UK & 29 & Korea & 53 \\
\hline Netherlands & 6 & Netherlands & 16 & Korea & 26 & UK & 43 \\
\hline New Zealand & 5 & Australia & 15 & Australia & 24 & Australia & 41 \\
\hline Korea & 5 & Korea & 14 & Netherlands & 22 & Netherlands & 34 \\
\hline Australia & 5 & France & 8 & Taiwan & 11 & China(mainland) & 23 \\
\hline Israel & 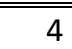 & New Zealand & 8 & New Zealand & 10 & Germany & 22 \\
\hline
\end{tabular}




\section{DISCUSSION AND CONCLUSION}

In this study, we present a co-authorship network-based method to quantify and describe the scholarly publication of a certain field. First, we generalized the measures used in previous literatures into formulas and analyzed the significance of the measures to make our analysis more precise. Secondly, to make our analysis clearer and more reasonable, we classified our study into four levels of overall, individual, institutional and international perspective. From these four perspectives, we can obtain the state of scholarly publication comprehensively, for example, obtaining the overall structural features of a certain field, discovering the differential opportunities and constraints that shape individuals' publishing behaviors, capturing the distribution of high-producing institutions from the location of them, and exploring the rules of collaboration publication between countries all over the world.

Based on all 1745 papers published in the international journals of MIS Quarterly, Information Systems Research and Journal of Management Information Systems from 1993 to 2012, this paper analyzed the state of scholarly publication in the field of information systems in the last two decades. A baseline assessment of the research out is beneficial for policy decisions maker to promote research. We carried out a detailed analysis such as productivity patterns, trends of the published research and status of international collaboration in this field and we conclude the findings as follows.

A total of 90 percent of papers were written by two or more authors, which mean that scholarly publication cooperation is a universal phenomenon in the field of IS. The details range of the collaboration degree of MISQ, ISR, JMIS and the total are respectively [1.96, 2.99], [1.89, 2.96], [2.25, 3.04] and [2.1, 2.99], implying that each article has two to three authors on average. The average collaboration degrees of the three elite journals are increasing slowly over the years with a few exceptions. This result indicates that the collaboration behavior of researchers in the field of information systems is augmenting with time. Most scholars (94\%) published no more than five articles while only 2 percent scholars published at least ten articles in the three elite journals. The number of articles published by scholars and institutions in the three elite journals all display a "long tail" phenomenon.

The number of yearly increased scholars fluctuates but generally keeps stable, which is approximately 100. By the year of 2012, the accumulated number of authors reaches to 2298 . This means that the IS field has a stable development in this aspect. The yearly increased institutions are around 30 each year. This result indicates that the research abilities of more and more institutions have been increasing and achieved international advanced level, and the growth trend is relatively stable. In the last two decades, the whole co-authorship network density in information systems faces a tendency of decline, from 0.0043 to 0.0016 . We found that the main reason is the number of scholars joining the collaboration network has increased, from 576 to 2298, which leads the maximum possible number of edges rocketing. Nevertheless, since the growth rate of the number of collaboration among scholars in the network is relatively limited, the network density shrinks.

By the year of 2012, the average distance achieves 5.85 in the collaboration authors' network, which means scientific information can be obtained easily by researchers who demand them. Through analyzing publishing outcomes of excellent scholars in famous institutions, we demonstrate that the ranking of an entire institution can be influenced by even one or two authors and the similar conclusion can be found in Chen et al (2013). We found that USA, Canada and Hong Kong are the three dominate countries in terms of outstanding scholars

Page | 12 
and educational resources concentrate, especially USA, which holds eight institutions of the top ten. Visiting scholars in the information systems discipline may select these countries and regions as the first choice for research visits and collaboration.

\section{ACKNOWLEDGEMENT}

This research was funded by four grants from the National Natural Science Foundation of China (\#71201039, \#71172157, \#71371059, \#71301035, \#71171068, and \#71531013). The research was also funded by a grant from the Science and Technology Plan Projects of the University of Jinan (\#XKY1720) and a grant from the Doctoral Initial Foundation of the University of Jinan (\#B1709).

\section{REFERENCES}

Abbasi, A., Altmann, J. and Hossain, L. 2011. Identifying the effects of co-authorship networks on the performance of scholars: A correlation and regression analysis of performance measures and social network analysis measures. Journal of Informetrics, Vol.5, no.4: 594-607.

Abbasi, A., Hossain, L., Uddin, S. and Rasmussen, K.J.R. 2011. Evolutionary dynamics of scientific collaboration networks: multi-levels and cross-time analysis. Scientometrics, Vol.89, no.2: 687-710.

Chen, Y., Börner, K. and Fang, S. 2013. Evolving collaboration networks in Scientometrics in 1978-2010: a micro-macro analysis. Scientometrics, Vol.95, no.3: 1051-1070.

Dennis, A.R., Valacich, J.S., Fuller, M.A., and Schneider, C. 2006. Research standards for promotion and tenure in information systems. MIS Quarterly, Vol.30, no.1: 1-12.

Elmacioglu, E. and Lee, D. 2009. Modeling idiosyncratic properties of collaboration networks revisited. Scientometrics, Vol.80, no.1: 195-216.

Heinze, T. and Kuhlmann, S. 2008. Across institutional boundaries? Research collaboration in German public sector nanoscience. Research Policy, Vol.37, no.5: 888-899.

Larivière, V. and Gingras, Y. and Archambault, E. 2006. Canadian Collaboration Networks: A Comparative Analysis of the Natural Sciences, Social Sciences and the Humanities. Scientometrics, Vol.68, no.3: 519-533.

Liu, C., Shan, W. and Yu, J. 2011. Shaping the interdisciplinary knowledge network of China: a network analysis based on citation data from 1981 to 2010. Scientometrics, Vol.89, no.1: 89-106.

Liu, H., Chang, B. and Chen, K.C. 2012. Collaboration patterns of Taiwanese scientific publications in various research areas. Scientometrics, Vol.92, no.1: 145-155.

Liu, X., Bollen, J., Nelson, M.L. and Van de Sompel, H. 2005. Co-authorship networks in the digital library research community. Information Processing and Management, Vol.41, no.6: 1462-1480.

Newman, M.E.J. 2001a. Scientific collaboration networks. II. Shortest paths, weighted networks, and centrality. Physical Review E, Vol.64, no.1: 016132. 
Newman, M.E.J. 2001b. Scientific collaboration networks. I. Network construction and fundamental results. Physical Review E, Vol.64, no.1: 016131.

Peffers, K. and Ya, T. 2003. Identifying and evaluating the universe of outlets for information systems research: ranking the journals. The Journal of Information Technology Theory and Application, Vol.5, no.1: 64-84.

Rainer, R.K. and Miller, M.D. 2005. Examining differences across journal rankings. Communications of the ACM, Vol.48, no.2: 91-94.

Ronda-Pupo, G.A. and Guerras-Martín, L.Á. 2010. Dynamics of the scientific community network within the strategic management field through the Strategic Management Journal 1980-2009: the role of cooperation. Scientometrics, Vol.85, no.3: 821-848.

Tang, L. and Shapira, P. 2011. Regional development and interregional collaboration in the growth of nanotechnology research in China. Scientometrics, Vol.86, no.2: 299-315.

Uddin, S., Hossain, L., Abbasi, A. and Rasmussen, K. 2012. Trend and efficiency analysis of coauthorship network. Scientometrics, Vol.90, no.2: 687-699.

Valacich, J.S., Fuller, M.A., Schneider, C. and Dennis, A.R. 2006. Issues and opinionsPublication opportunities in premier business outlets: How level is the playing field? Information Systems Research, Vol.17, no.2: 107-125.

Yazit, N. and Zainab, A.N. 2007. Publication productivity of Malaysian authors and institutions in LIS. Malaysian Journal of Library \& Information Science, Vol.12, no.2: 35-55.

Yin, L-C, Kretschmer, H., Liu, Z-Y. and Wang, B-L. 2006. Connection and stratification in research collaboration: An analysis of the COLLNET network. Information Processing and Management, Vol.42: 1599-1613.

Zhai, L., Yan, X., Shibchurn, J. and Song, X. 2014. Evolutionary analysis of international collaboration network of Chinese scholars in management research. Scientometrics, Vol.98, no.2: 1435-1454. 